HELMINTHOLOGIA, 52, 3: 229 - 235, 2015

\title{
Seasonal occurrence of some larval stages of endoparasites in three cyprinids from the Nwanedi-Luphephe dams, the Limpopo River System, South Africa
}

\author{
E. M. MBOKANE ${ }^{1,2}$, J. THERON² ${ }^{2}$ W. J. LUUS-POWELL ${ }^{3 *}$
}

\begin{abstract}
'Department of Agriculture, Forestry and Fisheries, Private Bag X2, Roggebay 8012, Cape Town, South Africa; ${ }^{2}$ Aquaculture Research Unit, University of Limpopo, Private Bag X1106, Sovenga 0727, South Africa; ${ }^{3}$ Department of Biodiversity, University of Limpopo, Private Bag X1106, Sovenga 0727, South Africa, *E-mail: wilmien.powell@ul.ac.za
\end{abstract}

\section{Article info}

Received October 17, 2014 Accepted January 28, 2015

\begin{abstract}
Summary
This study provides information on seasonal occurrence of developmental stages of endoparasites infecting three cyprinids in the Nwanedi-Luphephe dams, Limpopo River System. Labeobarbus marequensis (Smith, 1841), Barbus trimaculatus Peters, 1852 and Barbus radiatus Peters, 1853 were investigated seasonally from January 2008 to October 2008. The following larvae of metazoan parasites were collected: Diplostomum sp. from the eyes of $L$. marequensis and B. trimaculatus; Ornithodiplostomum $\mathrm{sp}$. from the gills of $B$. trimaculatus; Posthodiplostomum $\mathrm{sp}$. from muscle, skin and fins of $B$. trimaculatus and $B$. radiatus; third-stage Contracaecum larvae $(L 3)$ from the mesentery fats and on the liver lobes of $L$. marequensis and $B$. trimaculatus and gryporynchid cestode larvae from the outer intestinal wall of $B$. radiatus. All the flukes encountered were metacercariae. Diplostomum $\mathrm{sp}$. and Contracaecum sp. dominated the parasite communities. Their prevalence exhibited seasonal fluctuations with maxima in summer. Factors likely to influence fish infection such as the body size of fish and their condition factors were also briefly considered in this study.

Keywords: Limpopo River Systems; Labeobarbus marequensis; Barbus trimaculatus; Barbus radiatus; Diplostomum sp.; Ornithodiplostomum sp.; Posthodiplostomum sp.; Contracaecum sp.; gryporynchid cestode
\end{abstract}

\section{Introduction}

Larval forms of many helminth digeneans (flukes), cestodes (tapeworms) and nematodes (roundworms) use a variety of freshwater invertebrates such as snails and copepods as first intermediate hosts and fish species as second intermediate hosts, with the life cycle being completed in the intestinal tract of piscivorous birds (Barber et al., 2000). The migratory nature of piscivorous birds is crucial in the dispersal of endoparasites over long distances, hence making it difficult to control the spread of infections between water bodies in different catchments (Barson \& Avenant-Oldewage, 2006). Digeneans, cestodes and nematodes usually display a low specificity to both intermediate and definitive hosts that ensure their wide geographical distribution. Parasites could affect the health of fish, growth, behavior, fecundity and mortality and also regulate host population dynamics and community structure (Marcogliese, 2004).
The composition of fish endohelminth communities is influenced by numerous environmental and ecological factors such as the seasonal changes, geographical range, water characteristics, size and gender of the fish host, diet, abundance, mobility and life span of the fish, interdependence of parasites in the fish, as well as composition of fauna in the habitat (Lyholt \& Buchmann, 1996; Dörücü \& İspir, 2001; Dörücü et al., 2002; Campos et al., 2009, Alam et al., 2010). Ecological studies on parasites provide information about interrelationships between parasites, and their hosts about biodiversity of parasites and their distribution in a particular water system (Marcogliese, 2004; Vankara et al., 2011). The epidemiological data are particularly important when fish parasites are considered as the potential risks for aquaculture candidate species.

Therefore, the present study was conducted to obtain epidemiological data on larval helminth parasites of three cyprinid fish, namely Barbus trimaculatus Peters, 1852, Barbus radiatus Peters, 


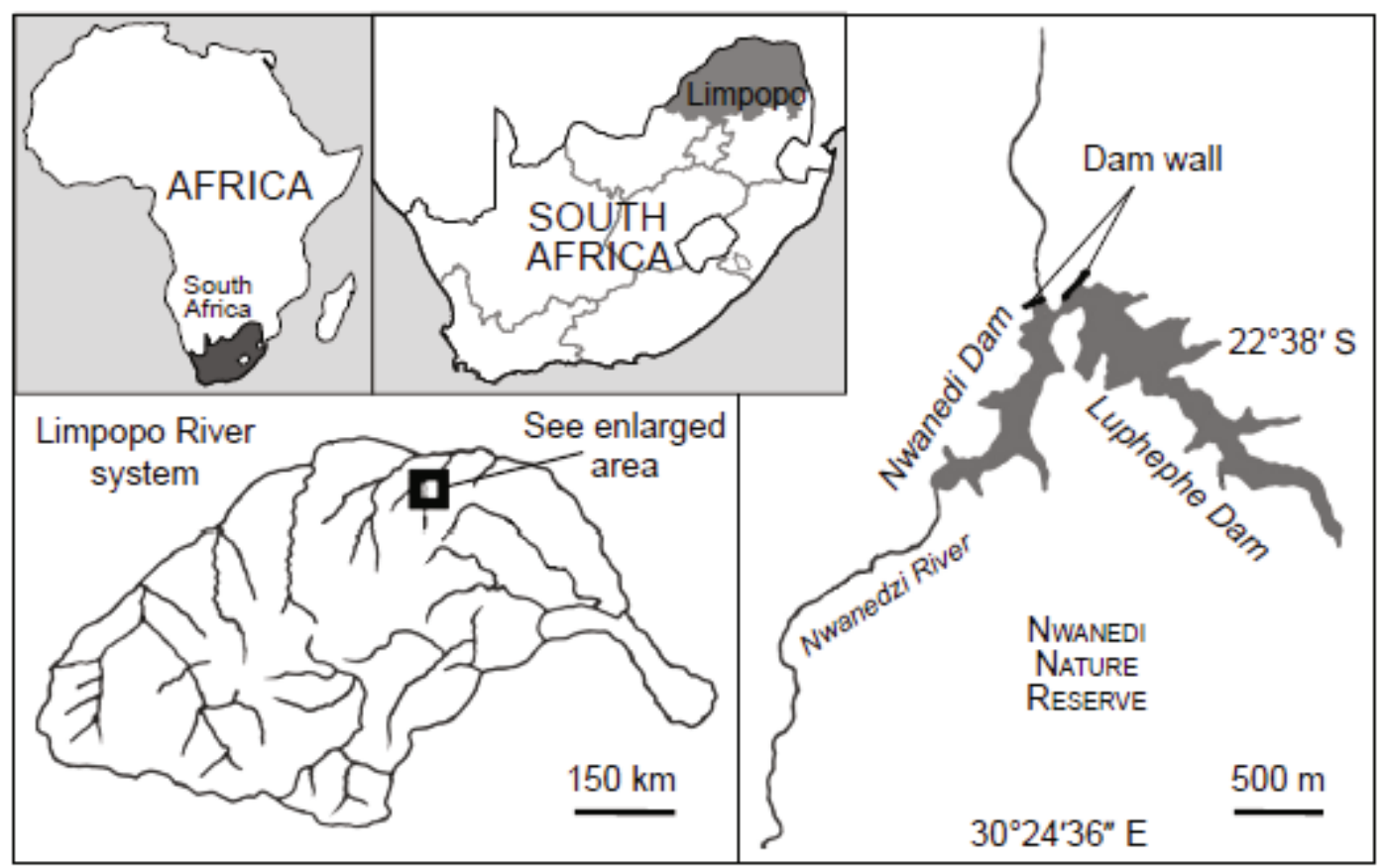

Fig. 1.The Nwanedi-Luphephe dams forms a part of the Limpopo River System, South Africa

1853 and Labeobarbus marequensis (Smith, 1841) in the Nwanedi-Luphephe dams from the Limpopo River System (South Africa). This work represents a part of a comprehensive research programme involving investigatingations of the parasite fauna of fish from the Nwanedi-Luphephe dams.

\section{Material and Methods}

\section{Study area}

The study was conducted at the Nwanedi-Luphephe dams (22 $2^{\circ} 39^{\circ} \mathrm{S}, 30^{\circ} 25^{\circ} \mathrm{E}$, altitude $600 \mathrm{~m}$ above sea level) situated within

Table 1. Summary of water quality variables measured seasonally at the Nwanedi-Luphephe dams in 2008 . Units are in $\mathrm{mg} / \ell$ unless otherwise indicated. Dashes denote unavailability of data.

\begin{tabular}{|c|c|c|c|c|c|}
\hline \multirow{2}{*}{ Water quality Variable } & \multicolumn{4}{|c|}{ Season } & \multirow{2}{*}{ TWQR } \\
\hline & Autumn & Winter & Spring & Summer & \\
\hline Temperature $\left({ }^{\circ} \mathrm{C}\right)$ & 23.1 & 17.4 & 27.7 & 27.2 & - \\
\hline Dissolved oxygen & 8.6 & 8.4 & 6.1 & 6.6 & $6-9$ \\
\hline $\mathrm{pH}$ & 7.6 & 7.2 & 7.7 & 8.0 & - \\
\hline Conductivity $(\mu \mathrm{S} / \mathrm{cm})$ & 0.06 & 0.06 & 0.07 & 0.08 & - \\
\hline Turbidity (NTU) & 2.2 & 1.4 & 2.6 & 4.2 & - \\
\hline Salinity (no unit) & -0.03 & -0.03 & -0.03 & -0.04 & - \\
\hline Total alkalinity $\left(\right.$ as $\left.\mathrm{CaCO}_{3}\right)$ & 20 & 20 & 24 & 24 & - \\
\hline Nitrate & $<0.2$ & $<0.2$ & $<0.2$ & 0.5 & 0.5 \\
\hline Nitrite & $<0.1$ & $<0.1$ & $<0.1$ & $<0.1$ & 0.2 \\
\hline Ammonium & $<0.2$ & $<0.2$ & $<0.2$ & $<0.2$ & 0.2 \\
\hline Ortho-phosphate & $<0.2$ & $<0.2$ & $<0.2$ & $<0.2$ & 0.10 \\
\hline Chloride (Cl) & 12 & 14 & 14 & 14 & 600 \\
\hline Sulphate $\left(\mathrm{SO}_{4}\right)$ & 5 & 6 & 6 & 5 & 100.0 \\
\hline Sodium $(\mathrm{Na})$ & 7 & 11 & 11 & 13 & 100 \\
\hline Potassium (K) & $<0.1$ & $<0.1$ & $<0.1$ & $<0.1$ & 200 \\
\hline Calcium (Ca) & 5 & 4 & 5 & 5 & - \\
\hline Magnesium (Mg) & 2 & 2 & 3 & 3 & 70.0 \\
\hline Aluminium (Al) & $<0.100$ & $<0.100$ & $<0.100$ & $<0.100$ & 0.01 \\
\hline Arsenic (As) & $<0.010$ & $<0.010$ & $<0.010$ & $<0.010$ & 100 \\
\hline Copper (Cu) & $<0.025$ & $<0.025$ & $<0.025$ & $<0.025$ & 0.500 \\
\hline Iron (Fe) & $<0.025$ & $<0.025$ & $<0.025$ & $<0.025$ & 0.020 \\
\hline Lead $(\mathrm{Pb})$ & $<0.020$ & $<0.020$ & $<0.020$ & $<0.020$ & 0.012 \\
\hline Manganese (Mn) & $<0.025$ & $<0.025$ & $<0.025$ & $<0.025$ & 0.180 \\
\hline Zinc $(Z n)$ & $<0.025$ & $<0.025$ & $<0.025$ & $<0.025$ & 1.000 \\
\hline
\end{tabular}

Key: TWQR=Target Water Quality range for South African aquatic ecosystems 
Table 2. Mean total length (mm) and condition factors of three cyprinids sampled at Nwanedi-Luphephe dams during the four seasons (January-October 2008)

\begin{tabular}{|c|c|c|c|c|c|c|c|}
\hline \multirow[b]{2}{*}{ Species } & \multirow[b]{2}{*}{ Season } & \multicolumn{2}{|c|}{ Fish length } & \multicolumn{2}{|c|}{ Weight } & \multicolumn{2}{|c|}{ Condition factor } \\
\hline & & Mean & $\pm S D$ & Mean & $\pm S D$ & Mean & $\pm S D$ \\
\hline & Autumn & 360.0 & 41.3 & 981.6 & 493.2 & 1.9 & 0.7 \\
\hline Labeobarbus & Winter & 187.1 & 53.2 & 176.9 & 109.9 & 2.3 & 0.3 \\
\hline \multirow[t]{4}{*}{ marequensis } & Spring & 309.3 & 105.1 & 711.5 & 629.1 & 2.2 & 0.2 \\
\hline & Summer & 392.0 & 53.1 & 1318.5 & 345.9 & 2.2 & 0.6 \\
\hline & Autumn & 30.7 & 2.2 & 0.5 & 0.1 & 1.8 & 0.4 \\
\hline & Winter & 31.7 & 5.3 & 0.7 & 0.3 & 2.1 & 0.5 \\
\hline \multirow[t]{3}{*}{ Barbus radiatus } & Spring & 59.1 & 9.6 & 5.3 & 2.3 & 2.4 & 0.3 \\
\hline & Summer & 41.2 & 7.9 & 1.7 & 1.6 & 2.1 & 0.6 \\
\hline & Autumn & 41.8 & 25.5 & 3.4 & 6.4 & 1.9 & 0.2 \\
\hline Barbus & Winter & 90.8 & 14.8 & 19.2 & 5.8 & 2.4 & 0.3 \\
\hline \multirow[t]{2}{*}{ trimaculatus } & Spring & 76.9 & 25.9 & 14.0 & 10.8 & 2.5 & 0.2 \\
\hline & Summer & 90.5 & 20.6 & 17.1 & 6.6 & 2.1 & 0.4 \\
\hline
\end{tabular}

$\pm S D$ = Standard deviation

the Nwanedi Nature Reserve in the Limpopo Province of South Africa (Fig. 1). The dams form twin impounds connected by a 2.5 $\mathrm{m}$ canal with a carrying capacity of 19.1 million $\mathrm{m}^{3}$. The drainage system of the dams forms part of the Limpopo River System. There are no agricultural, industrial and mining activities in close proximity to these dams (Oberholster et al., 2009).

A handheld YSI (556 MPS) measuring instrument was used to determine the water parameters and additional subsurface water parameters in situ during each survey (Table 1). The water samples were frozen and subsequently analyzed in accredited laboratory (ISO 17025, SANAS, Laboratory no. T0391). All water values did not exceed the limits specified by the South African target water quality range (TWQR) as indicated by the then Department of Water Affairs and Forestry (1996).

\section{Collection of hosts}

A total of 162 fish, L. marequensis $(n=53), B$. trimaculatus ( $n$ $=63$ ), and $B$. radiatus $(n=46)$ were caught using gill nets of stretched mesh sizes $30-110 \mathrm{~mm}$, cast nets, electro-fishing and seine nets over four seasonal periods in 2008: January (summer), April (autumn), July (winter), and October (spring). B. trimaculatus and $B$. radiatus were also collected in the streams feeding the dams. Live fishes were transported to the field laboratory and kept alive in aerated holding tanks until examination. Total length, weight and sex of each fish were recorded. Fish were sacrificed by severing the spinal cord, dissected and examined for parasites. Biometrical data on the three fish hosts and their condition factors are summarized in Table 2.

\section{Collection of parasites and parasitological analysis}

The eyes, brain, heart, stomach, intestine, liver, spleen, swim bladder and urinary bladder, body cavity, surface of the visceral organs and serous membrane were placed separately in Petri dishes containing a saline solution and examined microscopically for the presence of larval stages of endoparasites. Fixation, preservation, whole mount preparations as well as identification of parasites followed standard procedures by Pritchard and Kruse (1982). Due to difficulties in the identification of the larval forms to the species level, only the genus names of parasites were employed in the present paper.

\section{Data analysis}

The prevalence, mean abundance and mean intensity of each parasite were calculated according to Bush et al. (1997). A general linear model (GLM) was performed to ascertain which of the predictor variables (season, size, and sex) was associated with the infection level of the two predominant parasites, Diplostomum sp. and Contracaecum sp. Data were tested for normality and homogeneity of variance using the Shapiro-Normality test and Levene's test, respectively. The LSD (Least Significant Difference) post-hoc test was performed using SPSS 17.0 software package (SPSS Inc., Chicago, Illinois, USA) to determine the seasonal differences in the occurrence of the predominant parasites. A Pearson's correlation was performed to determine the relationship between the parasite burden and the fish length as well as between parasite burden and the condition factors of the fish. All statistical analyses were performed at the significance level of $5 \%$. 
Table 3. Seasonal occurrence of Diplostomum sp. and Contracaecum sp. from Labeobarbus marequensis at the Nwanedi-Luphephe dams

\begin{tabular}{llcccccc}
\hline Taxon & Season & No. of examined fishes $(\mathbf{n})$ & No. of fish infected & MA & MI & $\mathbf{P}(\%)$ & $\begin{array}{c}\text { Total No. } \\
\text { of parasites }\end{array}$ \\
\hline & Autumn & 15 & 13 & 8.8 & 10.2 & 86.7 & 132 \\
\multirow{2}{*}{ Diplostomum sp. } & Winter & 10 & 8 & 7.2 & 9.0 & 80.0 & 72 \\
& Spring & 10 & 10 & 9.7 & 9.7 & 100.0 & 97 \\
& Summer & 18 & 17 & 19.3 & 20.4 & 94.4 & 347 \\
\hline & Autumn & 15 & 4 & 4.5 & 16.8 & 28.0 & 67 \\
& Winter & 10 & 0 & 0.0 & 0.0 & 0.0 & 0 \\
& Spring & 10 & 1 & 0.3 & 3.0 & 10.0 & 3 \\
& Summer & 18 & 16 & 68.2 & 76.8 & 89.0 & 1228 \\
\hline
\end{tabular}

$\mathrm{MA}=$ mean abundance, $\mathrm{MI}=$ mean intensity, $\mathrm{P}=$ prevalence

The condition factor of fish was calculated as follows:

$C F=W \times 10^{5} / L^{3}$, where $C F=$ condition factor, $W=$ weight in grams and $L=$ total length in millimetres (Klemm et al., 1992).

\section{Results}

In total, three types of metacercariae larvae, gryporynchid cestode larvae and nematode-third-stage Contracaecum larvae (L3) were recorded in this study. Diplostomum sp. were collected from the eyes of $L$. marequensis (648) and B. trimaculatus (20) while a total of 177.0 Ornithodiplostomum sp. (encysted) from gills of $B$. trimaculatus (Table 4). Posthodiplostomum sp. encysted in the muscles, skin and fins of six B. trimaculatus (20) and five $B$. radiatus (17) during the winter survey (Table 4). Contracaecum sp. were collected from the mesentery fats in the body cavity and liver lobes of $L$. marequensis (1298) and B. trimaculatus (23) whereas the gryporynchid cestode larvae (Cyclophyllidae) was found from the external surface of the intestine of $B$. radiatus. The gryporhynchid cestode larvae (10 specimens) were isolated exclusively during the winter survey; with a mean intensity of 1.6 and a prevalence of $13.0 \%$.

The most abundant parasites were Diplostomum and Contracaecum sp. and their seasonal variations and infection statistics are summarised in Table 3. The overall occurrence (present or absent) of endoparasites recorded in this study is presented in Table 4 while Table 5 shows the overall level of infection calculated for each fish per parasite.

Diplostomum $\mathrm{sp}$. were the most abundant larvae throughout the sampling period. In B. trimaculatus, the prevalence of this parasite reached $10.0 \%$ and $12.2 \%$ in spring and in summer, respectively. The GLM model indicated that season significantly influenced the intensity of Diplostomum sp. ( $F=5.20, P<0.05)$. In the other host, L. marequensis, significant differences in the intensity of infection were found between summer and the remaining three periods of the year, but not between autumn and winter, autumn and spring as well as between winter and spring (LSD post-hoc test). The mean intensity of the Diplostomum sp. was 19.1 in summer compared to 10.2, 9.0 and 9.7 in autumn, winter and spring, respectively (Table 3). On the other hand, no significant effect of gender and size of the fish host on the intensity of Diplostomum sp. ( $F=1.01, P>0.05$; $F=0.12, P>0.05$, respectively) was observed. The Pearson's correlation results indicated only a weak, positive correlation between the mean intensity of Diplostomum sp. and the condition factor of L. marequensis $(r=0.09, P>0.05)$.

A prevalence of $20.0 \%$ for Contracaecum sp. (L3) in B. trimaculatus was recorded in the winter and summer surveys. The mean intensity was 2.7 and 5.0 in these samplings, respectively. No Contracaecum larvae were found in this host during autumn and spring. The GLM and Pearson correlation analyses indicated no

Table 4. Presence of larval stages of endoparasites in three cyprinids during different seasons in 2008 at the Nwanedi-Luphephe dams

\begin{tabular}{|c|c|c|c|c|c|}
\hline \multirow{2}{*}{ Parasite groups } & \multirow{2}{*}{ Taxon } & \multicolumn{4}{|c|}{ Sampling periods } \\
\hline & & April & July & October & January \\
\hline \multirow[t]{3}{*}{ Digenea } & Diplostomum sp. & + & + & + & + \\
\hline & Posthodiplostomum sp. & - & + & - & - \\
\hline & Ornithodiplostomum sp. & + & + & + & + \\
\hline Cestoda & Gryporhynchid larvae & - & + & - & - \\
\hline Nematoda & Contracaecum sp. & + & - & + & + \\
\hline
\end{tabular}


Table 5. Overall level of infection of parasites for three fish species from Nwanedi-Luphephe dams (January-October 2008)

\begin{tabular}{llccc}
\hline Host species & Parasite species & MA & MI & P (\%) \\
\hline \multirow{2}{*}{ Labeobarbus marequensis } & Diplostomum sp. & 12.2 & 13.5 & 90.6 \\
& Contracaecum sp. & 24.5 & 61.8 & 39.6 \\
\hline \multirow{4}{*}{ Barbus trimaculatus } & Diplostomum sp. & 0.3 & 2.8 & 11.1 \\
& Ornithodiplostomum sp. & 2.8 & 4.0 & 69.8 \\
& Posthodiplostomum sp. & 0.3 & 3.3 & 9.5 \\
& Contracaecum sp. & 0.3 & 3.8 & 9.5 \\
\hline \multirow{2}{*}{ Barbus radiatus } & Posthodiplostomum sp. & 0.4 & 4.3 & 10.9 \\
& Gryporynchid larvae & 0.2 & 1.6 & 13.0 \\
\hline MA = mean abundance $\mathrm{MI}=$ mean intensity P = prevalence & & &
\end{tabular}

effect of season and condition factor of the fish host on the intensity of infection of Contracaecum sp. in L. marequensis.

\section{Discussion}

Diplostomum sp. and Contracaecum larvae were previously recorded from $L$. marequensis as well as from other fish species in South Africa (Olivier et al., 2009; Smit \& Luus-Powell, 2011; Madanire-Moyo et al., 2012). A high prevalence and intensity of infection of the two parasites were also recorded in $B$. trimaculatus in this study. In the present study, the maximum prevalence and intensity of Diplostomum sp. occurred in summer, most probably due to higher water temperature in this season. More intense cercarial production associated with the increasing water temperature was formerly reported by Stables and Chappell (1986), Taskinen et al. (1994) and Lyholt and Buchmann (1996). Wang et al. (2001) reported that the release of the free-swimming cercariae of Dollfustrema vaneyi (Echmann, 1934) in warm seasons contributed to higher infection levels in the bullhead catfish Pseudobagrus fulvidraco (Richardson, 1846) in China.

Life cycles of endoparasites are complex with multiple intermediate and often migratory definitive hosts and, thus, consequent infection values may be assigned to the richness and availability of appropriate hosts. Different feeding patterns of the fish could also play a significant role in the diverse abundance of their parasites. Labeobarbus marequensis is an omnivorous fish species (Skelton, 2001), a diet of which is mostly composed of snails and crustaceans (intermediate hosts of Contracaecum sp.). Contrary to that, $B$. trimaculatus feeds mostly on phytoplankton that limits its possibility to be infected.

The abundance of Diplostomum sp. and Contracaecum sp. may also be influenced by the type of habitat. Lentic ecosystems provide specific conditions, such as the higher water temperature and lower water currents (Ondračková et al., 2004), which facilitates concentration of the first and second intermediate hosts, thus increasing the probability of the cercariae locating its host. In addition, these conditions make the second intermediate host more vulnerable to predation by piscivorous birds. The high intensities of Diplostomum sp. and Contracaecum sp. recorded in L. mareq- uensis in the present study coincided with the low water levels in the dams, in contrast to B. trimaculatus collected in the streams, which was free of parasites.

The present study evidenced no relationship between parasite burden and the condition factor of the fish host. In natural conditions, many parasites exist in benign relationships with their hosts, without causing any obvious distress. Nevertheless, high numbers of Diplostomum sp. are associated with several fish diseases such as exophthalmia, local haemorrhage, lens cataract, which may yet lead to fish mortality. None of these symptoms were observed in the present study.

Results of this study also showed that the prevalence and intensity of Contracaecum sp. and Diplostomum sp. were not influenced by the size of the host. It is generally known that the size of fish may have an impact on the occurrence of parasites. Larger fish usually have higher numbers of parasites, which can be attributed to the larger surface area providing more space and food resources to parasites. Fish investigated herein have different body size: The maximum length of $L$. marequensis is $470 \mathrm{~mm}$ and that of $B$. trimaculatus and $B$. radiatus only $120 \mathrm{~mm}$ (Skelton, 2001). The number of parasites recorded in this study was also higher in larger fish.

The metacercariae embedded in gills of $B$. trimaculatus closely resembled the Ornithodiplostomum sp. collected by Barson and Avenant-Oldewage (2006) from the muscles of catfish Clarias gariepinus (Burchell, 1822). Although the life cycle of these parasites is similar to other diplostomoids and a number of related genera such as Diplostomum, Neodiplostomum and Posthodiplostomum are quite common in the Limpopo Province (Khalil \& Polling, 1997), Ornithodiplostomum sp. has not been registered in this area before. Our finding of Ornithodiplostomum sp. in B. trimaculatus represents a new host and geographical record.

Posthodiplostomum sp. is referred as a causative agent of black grub or black spot disease and are located in spherical or oval bead-like cysts embedded in the fish muscle, or under the skin and on the fins. According to Lane and Morris (2000), the outer black cyst wall is of host origin (cells of the host) and inner transparent cyst are formed by secretions of the parasite, which leads to clearly recognizable black spots in the muscle, skin and fins of the host. The low number of fish infected with Posthodiplostomum sp. may 
suggest a scarcity of suitable intermediate hosts in the Nwanedi-Luphephe dams and thus, Posthodiplostomum sp. metacercariae do not represent a serious threat to fish health in this locality. Larval stages of a gryporhynchid cestode were found in the outer intestinal wall of $B$. radiatus during the winter survey. Generally, low infection levels of these metacestodes might be related to the fact that gryporhynchid larvae are often overlooked due to their minuscule size and specific site. Mashego (2001) recorded a prevalence of only $4.0 \%$ of these metacestodes in $B$. radiatus and mean intensities of $1.0-6.0$ specimens with prevalence ranging from $4.0-13.0 \%$ in other five cyprinids from the Limpopo Province. Water quality variables measured in this study show that the Nwanedi-Luphephe dams are relatively un-polluted. During the entire course of the survey, levels of the selected physico-chemical parameters measured were relatively low and within permissible TWQR range. This agrees with previous studies from the Nwanedi-Luphephe dams, chacterizing them as essentially unpolluted due to little urban development, absence of intensive agricultural, industrial and mining activities in the area (Oberholster et al., 2009; Madanire-Moyo et al., 2012). The infective stages are considered highly sensitive to adverse water conditions, therefore, their presence or absence may serve as an indication of the status of the water body (Tieri et al., 2006). Our results demonstrated that the quality of the environment favored development of larval stages of various parasites in their intermediate hosts. Although all the above-mentioned larval stages have previously been recorded from other fish species in South Africa, nevertheless, they represent new ecological records for the Nwanedi-Luphephe dams.

\section{Acknowledgements}

The authors thank students from the Department of Biodiversity and the Aquaculture Research Unit, UL, for technical assistance in fish necropsy and field work. We also wish to thank Prof. PAS Olivier, Dr. MM Matla, Dr. GN Madanire-Moyo, Mr. WJ Smit and Mr. HE Hattingh who assisted with field work. The funding for this study was provided by the National Research Foundation (NRF); and the Research Development and Administration of the University of Limpopo.

\section{References}

Alam, M.D., Rakibuzzaman, J., Hasan, M.M. (2010): Comparative study of endo-parasitic infestation in Channa punctatus (Bloch, 1793) collected from hatchery and sewage lagoon. Nat. Sci., 8(5): 152 - 155. DOI:10.3329/diujst.v6i2.9339

Barber, I., Hoare, D., Krause, J. (2000): Effects of parasites on fish behavior: a review and evolutionary perspective. Rev. Fish Biol. Fish., 10: 131 - 165. DOI: 10.1023/A:1016658224470

Barson, M., Avenant-Oldewage, A. (2006): On cestode and digenean parasites of Clarias gariepinus (Burchell, 1822) from the Rietvlei Dam, South Africa. Onderstepoort J. Vet. Res., 73: 101 - 110. DOI: 10.4102/ojvr.v73i2.154

Bush, A.O., LAfFerty, K.D., LotZ, J.M., Shostak, A.W (1997): Parasitology meets ecology on its own terms: Margolis et al. revisited. J. Parasitol., 83: 575 - 583. DOI: 10.2307/3284227
Campos, C.M., Fonseca, V.E., Takemoto, R.M., Moraes, F.R. (2009): Ecology of the parasitic endohelminth community of Pseudoplatystoma fasciatum (Linnaeus, 1776) (Siluriformes: Pimelodidae) from the Aquidauana River, Pantanal, State of Mato Grosso do Sul, Brazil. Braz. J. Biol., 69(1): 93 - 99. DOI: 10.1590/S151969842009000100011

Department of Water Affairs and Forestry (1996): South African Water Quality Guidelines. Volume 7: Aquatic Ecosystems. Pretoria, $145 \mathrm{pp}$.

DöRÜcü M., İsPIR, Ü. (2001): Seasonal Variation of Diplostomum sp. infection in eyes of Acanthobrama marmid Heckel, 1843 in Keban Dam Lake, Elazığ, Turkey. E.U. J. Fish. Aquat. Sci., 18(3 - 4): $301-305$

Dörücü, M., Dılsız, N., Grabbe, M.C.J. (2002): Occurrence and Effects of Diplostomum sp. infection in Eyes of Acanthobrama marmid in Keban Dam Lake, Elazığ, Turkey. Turk. J. Vet. Anim. Sci., 26: $239-243$

Kennedy, C.R. (1984): The use of frequency distributions in an attempt to detect host mortality induced by infections of diplostomatid metacercariae. Parasitology, 89: 209 - 220. DOI: 10.1017/ S0031182000001244

KHALIL, L.F., PoluING, L. (1997): Check list of the helminth parasites of African freshwater fishes. Department of Zoology/Biology, University of the North, Sovenga, South Africa, $185 \mathrm{pp}$.

Klemm, D.J., Strober, G.J., Lazorchak, J.M. (1992): Fish field and laboratory methods for evaluating the biological integrity of surface waters. EPA/600/R-92-111 USEPA, Cincinatti, Ohio.

LANe, R.L., Morris, J.E. (2000): Biology, Prevention, and Effects of Common Grubs (Digenetic trematodes) in Freshwater Fish. Tech. Bull. Series \# 115: 7 pp.

LyHOLt, H.C.K., BuchmanN, K. (1996): Diplostomum spathaceum: effects of temperature and light on cercarial shedding and infection of rainbow trout. Dis. Aquat. Org., 25: 169 - 173. DOI: 10.3354/ dao025169

Madanire-Moyo, G.N., Matla, M.M., Olivier, P.A.S., Luus-Powell, W.J. (2011): Population dynamics and spatial distribution of monogeneans on the gills of Oreochromis mossambicus (Peters, 1852) from two lakes of the Limpopo River System, South Africa. J. Helminthol., 85: 146 - 152. DOI: 10.1017/S0022149X10000301

Madanire-Moyo, G.N., Luus-Powell, W.J., Olivier, P.A. (2012): Diversity of metazoan parasites of the Mozambique tilapia, Oreochromis mossambicus (Peters, 1852), as indicators of pollution in the Limpopo and Olifants River systems. Onderstepoort J. Vet. Res., 79(1): Art. \#362, 9 pages. DOI: 10.4102/ojvr.v79i1.362 MARcogliese, D.J. (2004): Parasites: small players with crucial roles in the ecological theatre. EcoHealth, 1(2): 51 - 164. DOI: 10.1007/s10393-004-0028-3.

MAshego, S.N. (2001): Redescription of Proteocephalus glanduliger (Janicki, 1928) Fuhrmann, 1933 (Cestoda: Proteocephalidae: Proteocephalinae). Ann. Transvaal Mus., 38: 13 - 17. DOI: 10.1007/s11230-008-9153-7

Oberholster, P.J., Ashton, P.J., Macmillan, P.M. (2009): A water quality reconnaissance investigation of the Nwanedzi Dam, Limpopo Province. Report (GWDMS 175044), CSIR (Natural Resources and the Environment), Pretoria, $16 \mathrm{pp}$.

Olivier, P.A.S., Luus-Powell, W.J., SaAyman, J.E. (2009): Report 
on some monogenean and clinostomid infestations of freshwater fish and waterbird hosts in Middle Letaba Dam, Limpopo Province, South Africa. Onderstepoort J. Vet. Res., 76: 187 - 199. DOI: 10.4102/ojvr.v76i2.44

Ondračková, M., Šimková, A., Gelnar, M., JuRajda, P. (2004): Posthodiplostomum cuticola (Digenea: Diplostomatidae) in intermediate fish hosts: factors contributing to the parasite infection and prey selection by definitive bird host. Parasitology, 129: 761 - 770 . DOI: 10.1017/S0031182004006456

Pritchard, M.H., Kruse G.O. (1982): The collection and preservation of animal parasites. Univ. Nebraska Press, Lincoln and London SIBLEY, P.K., DIXON, F.G., BARTON, D.R. (2000): Impact of bleached kraft pulp mill effluent on benthic community structure in relation to environmental factors. J. Aquat. Stress Recovery, 7: 229 - 246. DOI: 10.1023/A:1009987123319

Smit, W.J., LUUS-PoWELL, W.J. (2011): The occurrence of metazoan endoparasites of Schilbe intermedius Rüppell, 1832 from the Nwanedi-Luphephe Dams in the Limpopo River System, South Africa. Afr. Zool., 47(1): 35 - 41. DOI: 10.3377/004.047.0123

Stables, J.N., Chappell, L.H. (1986): Diplostomum spathaceum
(Rud. 1819): effects of physical factors on the infection of rainbow trout (Salmo gairdneri) by cercariae. Parasitology, 93: 71 - 79. DOI: $10.1017 /$ S0031182000049830

SKELton, P.H. (2001): A complete guide to the freshwater fishes of Southern Africa. Halfway House, Cape Town, 395 pp.

TAskinen, J., Valtonen, E.T., MäkelÄ, T. (1994): Quantity of sporocysts and seasonality of two Rhipidocotyle species (Digenea: Bucephalidae) in Anodonta piscinalls (Mollusca: Bivalvia). Int. J. Parasitol., 24: 877 - 886

Tieri, E., Mariniello, L., Ortis, M., Berti, M., Battistini, M.L. (2006): Endoparasites of chub (Leuciscus cephalus) in two rivers of the Abruzzo region of Italy. Vet. Ital., 42(3): $271-279$

Vankara, P.A., Mani, G., ViJayalakshmi, C. (2011). Metazoan parasite infracommunities of the freshwater eel, Mastacembelus armatus Lacèpéde, 1800 from River Godavari, India. Int. J. Zool. Res., 7: 19 - 33. DOI: 10.3923/ijzr.2011.19.33

WANG, G.T., YAO, W.J., NIE, P. (2001): Seasonal occurrence of Dollfustrema vaneyi (Digenea: Bucephalidae) metacercariae in the bullhead catfish Pseudobagrus fulvidraco in a reservoir in China. Dis. Aquat. Org., 44: 127 - 131. DOI: 10.3354/dao044127 